made a special study of linear earthworks, has also placed his information at the disposal of the Department. No excavations have been undertaken to fill in gaps, but the hope is expressed that archæologists, to whom the map is dedicated, will amplify by their labours the next edition. In a foreword, attention is directed to certain features of the map. A large number of 'barrow circles' have been located by air photography which are here recorded for the first time. Accordingly it has been thought necessary for the sake of consistency to show all barrows from neolithic to Saxon, the long barrows being numbered in accordance with the numbering in the map of Neolithic Wessex. Attention is also directed to the information afforded by the map on the movements of settlement in instances in which the site of cultivation appears to have been stationary and also to that bearing on the purpose of linear earthworks.

\section{Standardisation in Anthropometry}

A prectminary statement, to form a basis of discussion, has been issued by the International Committee for Standardization of the Technique of Physical Anthropology and is published in Man of June. This Committee was appointed by the International Federation of Eugenics Organizations at its New York meeting on the understanding that, in the event of an international organisation for anthropology being formed, the Standardization Committee would be free to transfer itself to that body. As this condition has now been fulfilled by the institution of an International Congress of Anthropological and Ethnological Sciences, the question of the future of the Committee will be discussed at the forthcoming meetings of the Federation and the Congress. In the meantime, the document now published by the Committee makes certain suggestions for future action, pointing out that while anthropologists have met on several previous occasions to deplore the lack of system and uniformity in anthropometric measurement, no practical result has followed. It is now suggested that a number of regional committees should be formed, and that each of these should discuss the revision of systems of measurement on both living and skeletal material, which after testing, criticism and revision, might be put forward as regional schemes to form the basis of international discussion. As the urgent need for reform is widely recognised, a determined effort to arrive at agreement should be possible, even though revision is likely to prove a lengthy undertaking.

\section{New Oil Well Drilling Record}

A NEW record for deep oil well drilling has been established by the General Petroleum Corporation in the South Belridge Field, San Joaquin Valley, California, by the achievement of a depth of 11,377 ft. (approximately $2 \cdot 15$ miles). This is the first oil well which has been drilled to more than $11,000 \mathrm{ft}$. and must be considered a remarkable engineering achievement. The well was started in September 1930 and continued until March 1932 when, owing to a 'cut' in the development programme, operations were stopped. Drilling was resumed in August 1933 and the final depth recorded above was reached at the end of May of this year. An equally notable feature of this performance is that a substantial $4 \frac{3}{4}$-in. casing string has been landed successfully at the bottom. There have already been shows of oil and gas in this well, but these have to some extent been smothered by the enforced use of large quantities of very heavy mud held at between 104 and $112 \mathrm{lb}$. per cubic foot to overcome the high gas pressures met with. The Oil Weekly of June 11 gives a detailed account of this well and concludes that improved technique and engineering equipment are the outstanding factors which have made this record possible.

\section{Everglades National Park, U.S.A.}

AFTER a certain amount of opposition, Bills for the creation of a National Park in the Everglades of Florida have passed Senate and Congress (Science Service, Washington, D.C.). The park to be created will comprise $1,300,000$ aeres, and will be unique amongst the larger national parks in lacking mountains. The fauna is tropical, comprising snakes and alligators, several beautiful herons, spoon-bills and the almost extinct 'bone-headed' ibis, and characteristic vegetation. Beyond the coast the park will extend to several of the small islands or 'keys', so that a sample of the rich tropical marine fauna will be available to the visitor. Access to the area will apparently be from the present road, the Tamiami Trail, on the northern boundary of the reserve, but further exploration can be made only on foot or in canoes under the guidance of Seminole Indians. Interest is added to the scheme by the proposal to establish a new Seminole reservation to the north of the Tamiami Trail, in elose proximity to the Park itself.

\section{Health of the Navy during 1932}

IN the "Statistical Report of the Health of the Navy for the Year 1932", recently issued (London : H.M. Stationery Office. 2s. 6d. net), the Medical Director-General of the Navy, Sir R. St. G. S. Bond, states that in a force of 83,285 , the total number of cases of disease and injury was 39,284 , equivalent to a ratio of 471.68 per thousand, an increase of 6.12 in comparison with the five years' average, and a decrease of 19.82 in relation to 1931 . Only four cases of typhoid fever and eight cases of paratyphoid fever occurred during the year. Fifteen cases of undulant fever were returned, of which twelve were from the Mediterranean Station. Venereal diseases have declined in number, the fresh admissions totalling 4,638 as compared with 4,962 in 1931. Details are given of some of the cases of interest that have occurred, and of research work.

\section{Chimpanzee Twins}

Dr. Robert M. Yerkes has described the first authentic recorded case of the appearance of twins in an anthropoid ape family (Science, May 11, 1934). 